A

$\mathbf{R}$

$\mathbf{T}$

Y $\quad \mathbf{K}$

$\mathbf{U}$

$\mathbf{L}$

$\mathbf{Y}$

ROCZNIKI TEOLOGICZNE

Tom LXVI, zeszyt 12 - 2019

DOI: http://dx.doi.org/10.18290/rt.2019.66.12-1

KS. RAFAŁ BINIEK

\title{
ŚLADY BOGA W STWORZONYM ŚWIECIE. TEOLOGIA NATURY A NAUCZANIE KOŚCIOŁA I PRZEPOWIADANIE NA TEMATY EKOLOGICZNE
}

\author{
TRACES OF GOD IN THE CREATED WORLD. \\ THEOLOGY OF NATURE AND CHURCH TEACHING AND PREACHING \\ ON ECOLOGICAL ISSUES
}

\begin{abstract}
A b s t r a c t. The encyclical Laudato si' by pope Francis shows the importance of ecological themes for the Church of our time. They shouldn't be lacking in the proclamation of the Word of God. This article is an attempt to respond to this challenge based on the theology of nature, which consists in searching for traces of God in the world. Its starting point is the theological concept of the nature as the creature and the idea of the universal revelation of God in the created world. After discussing the main premises of the theology of nature, ethical consequences of this conception (conservation of nature as a religious obligation resulting from the faith in God as the creator of the world) and hints concerning the possibilities of using the impulses arising from the theology of nature in ecclesiastical preaching were presented.
\end{abstract}

Key words: nature; creation; universal revelation; ecology; conservation of nature; preaching.

W dwunastym punkcie encykliki Laudato si Papież Franciszek przypomina postać swojego wielkiego imiennika, św. Franciszka z Asyżu, którego duchowość wyrażała się m.in. w kontemplacji przyrody, którą uważał on za „wspa-

Ks. dr RAFAŁ BINIEK - habilitant w Katedrze Teologii Fundamentalnej na Wydziale Teologicznym Katolickiego Uniwersytetu Eichstätt-Ingolstadt; adres do korespondencji: Eckbertstr. 30, 96052 Bamberg, Niemcy; e-mail: rbiniek1986@gmail.com; ORCID: 0000-00033935-8184. 
niałą księgę, w której Bóg do nas mówi i przekazuje nam coś ze swego piękna i dobroci" ". W tym samym punkcie Ojciec Święty cytuje dwa fragmenty Pisma Świętego, które uzasadniają przekonanie o uniwersalnym objawieniu się Boga w stworzonym świecie i o możliwości naturalnego poznania Boga, a mianowicie Mdr 13,5 (,z wielkości i piękna stworzeń poznaje się przez podobieństwo ich Stwórcę”) oraz Rz 1,20 („Jego potęga oraz bóstwo stają się widzialne dla umysłu przez Jego dzieła"). To przekonanie, potwierdzone przez Sobór Watykański I w Konstytucji dogmatycznej Dei Filius, stoi u podstaw teologii naturalnej, która - choć jej początki w świecie chrześcijańskim sięgają czasów wczesnochrześcijańskich apologetów - rozwinęła się przede wszystkim w ramach filozofii i teologii scholastycznej oraz w nawiązującej do niej neoscholastyce XIX i XX wieku. Ta forma teologii naturalnej, która niezależnie od wiary i Objawienia, niejako w ich przedsionku, tylko i wyłącznie za pomocą naturalnego światła ludzkiego rozumu próbowała udowodnić istnienie Boga oraz poznać jego istotę ${ }^{2}$, spotkała się z ostrym sprzeciwem teologii luterańskiej, zwłaszcza Karla Bartha, według którego poznanie Boga możliwe jest tylko i wyłącznie poprzez Objawienie w Jezusie Chrystusie ${ }^{3}$, natomiast teologia naturalna jest dziełem Antychrysta ${ }^{4}$. Również współczesna teologia katolicka, zwłaszcza po Soborze Watykańskim II, wyraźnie dystansuje się od dominującej wcześniej neoscholastyki oraz rozwijanej przez nią czysto filozoficznej teologii naturalnej. Nie musi to jednak oznaczać całkowitego odrzucenia nauki o możliwości naturalnego poznania Boga. W niniejszym artykule chciałbym przedstawić inną koncepcję teologii naturalnej, opartą na stricte teologicznym pojęciu natury jako stworzenia, którą dla odróżnienia od jej neoscholastycznej poprzedniczki nazywam po prostu „teologią natury" ". Chciałbym też wykazać, że może być ona ważnym źródłem i punktem odniesienia dla kościelnego nauczania i przepowiadania na tematy związane z ekologią, która należy do szeroko rozumianej tematyki społecznej, na

\footnotetext{
${ }^{1}$ FrANCISZEK, Encyklika Laudato si'. W trosce o wspólny dom, Wydawnictwo M, Kraków 2015, nr 12.

${ }^{2}$ Por. G. KRAUS, Gotteserkenntnis ohne Offenbarung und Glaube? Natürliche Theologie als ökumenisches Problem, Bonifatius-Druckerei, Paderborn 1987, s. 25.

${ }^{3}$ Por. K. BARTH, Katholische Dogmatik II/1, Theologischer Verlag, Zürich 1940, s. 189.

${ }^{4}$ Por. K. BARTH, Nein! Antwort auf Emil Brunner, Verlag C. Kaiser, München 1934, s. 63.

${ }^{5}$ Określenia tego używa np. Viggo Mortensen. Zob. V. Mortensen, Theologie der Natur als natürliche Theologie, w: Kann man Gott aus der Natur erkennen? Evolution als Offenbarung, QD 125, red. C. Bresch, S.M. Daecke, H. Riedlinger, Verlag Herder, Freiburg im Breisgau 1990, s. 117-134.
} 
co wskazuje np. socjolog Piotr Marczak w książce pt. Problemy ekologiczne jako problemy spoteczne ${ }^{6}$.

\section{TEOLOGICZNE POJĘCIE NATURY}

Kluczowe znaczenie dla teologii natury ma rozumienie słowa „natura”. Niewiele jest pojęć, które są używane w tak wielu różnych kontekstach, jak właśnie natura: począwszy od języka codziennego poprzez świat kultury, różne dziedziny nauk przyrodniczych i humanistycznych aż po filozofię i teologię. Również w ramach poszczególnych językowych kontekstów słowo to występuje w różnych znaczeniach i jego rozumienie podlega historycznym zmianom. Termin ten wywodzi się z języka łacińskiego i pochodzi od czasownika nascor, nasci - „rodzić się”. Niemiecka filozof Petra Kolmer rozróżnia dwa podstawowe znaczenia słowa ,natura": kwantytatywne i kwalitatywne. Zgodnie z tym pierwszym natura to obszar rzeczywistości, który nie został uczyniony lub zmieniony przez działalność człowieka, czyli krótko mówiąc świat przyrody oraz zachodzące w nim zjawiska i procesy. Natomiast w znaczeniu kwalitatywnym natura oznacza istotę, czyli zbiór cech charakterystycznych dla określonych bytów lub zjawisk. W tym sensie można mówić o naturze ludzkiej lub boskiej, ale również o naturze zwierząt, roślin, przedmiotów itd. ${ }^{7}$ Obydwa te znaczenia są obecne również w języku teologicznym.

W historii teologii szczególną rolę odegrało pojęcie natury jako przeciwieństwa łaski ${ }^{8}$. Chodzi w nim o naturę ludzką rozumianą jako istotę człowieka upadłego i jeszcze nieodkupionego, a więc pozbawionego Bożej łaski.

\footnotetext{
${ }^{6}$ P. MarczaK, Problemy ekologiczne jako problemy spoteczne, Seria Socjologia nr 27, Uniwersytet Adama Mickiewicza, Poznań 2000.

${ }^{7}$ Por. P. Kolmer, Warum Streit um die Evolutionstheorie? Anmerkungen zur Vereinbarkeit von Glauben und Wissen, w: Gott und Natur. Philosophische Positionen zum aktuellen Streit um die Evolutionstheorie, red. P. Kolmer, K. Köchy, Verlag Karl Alber, Freiburg-München 2011, s. 13-50, tutaj: s. 33 .

${ }^{8} \mathrm{Na}$ temat problemu relacji natury i łaski powstało bardzo wiele literatury. Zob. np. następujące pozycje: K. RAHNER, Über das Verhältnis von Natur und Gnade, w: Schriften zur Theologie I, 4. Auflage, Verlag Benziger, Einsiedeln 1960, s. 323-345; U. KÜHN, Natur und Gnade. Untersuchungen zur deutschen katholischen Theologie der Gegenwart, Evangelische Verlagsanstalt, Berlin 1961; W. SimONIS, Natur und Gnade, „Catholica-Münster” 19(1965), s. 310-324; T. KосH, Natur und Gnade. Zur neueren Diskussion, „Kerygma und Dogma” 16(1970), s. 171-187; D. BERGER, Natur und Gnade in systematischer Theologie und Religionspädagogik von der Mitte des 19. Jahrhunderts bis zur Gegenwart, Verlag Roderer, Regensburg 1998.
} 
Zwłaszcza w teologii neoscholastycznej została rozwinięta nauka o podziale rzeczywistości na dwa całkowicie odrębne i samodzielne obszary tego, co naturalne i tego, co ponadnaturalne. Ta druga sfera była utożsamiana $\mathrm{z}$ łaską i pełniła w dwupiętrowej strukturze ludzkiego bytu rolę nadbudowy, tzn. stanowiła uzupełnienie i ukoronowanie natury człowieka ${ }^{9}$. Właśnie to kwalitatywne pojęcie natury stoi u podstaw tradycyjnej teologii naturalnej, opartej na przekonaniu, że człowiek za pomocą naturalnego światła rozumu, czyli niezależnie od Bożego Objawienia i łaski, jest w stanie poznać Boga, a dokładniej Jego istnienie $\mathrm{i}$ istotę. Wbrew swojej nazwie stanowiła ona dyscyplinę filozoficzną, a nie teologiczną, a jej wyniki były traktowane jako preambula fidei, czyli rozumowe przesłanki wiary. Można powiedzieć, że teologia naturalna była umiejscowiona $\mathrm{w}$ przedsionku wiary, a jej zadaniem było dostarczenie danych rozumowych prowadzących do przyjęcia wiary chrześcijańskiej i umożliwiających jej uzasadnienie, czyli wykazanie jej rozumności i wiarygodności.

Kwalitatywne pojęcie natury jest znane również z trynitologii i chrystologii. W ramach tej pierwszej jest mowa o jednej naturze i trzech Osobach Bożych, natomiast w ramach tej drugiej podkreśla się istnienie dwóch natur w Jezusie Chrystusie: natury boskiej i natury ludzkiej.

W kontekście naszego tematu znacznie bardziej interesuje nas jednak teologiczna wersja kwantytatywnego pojęcia natury, a więc rozumienie natury jako stworzenia, a dokładniej całości stworzonej przez Boga rzeczywistości, do której należy świat przyrody oraz człowiek, nazywany czasem korona stworzenia.

Nie brakuje autorów, którzy uważają „naturę” i „stworzenie” za dwa alternatywne pojęcia, należące do różnych światopoglądów. Przykładem jest Romano Guardini, który pisze, że świat nie jest naturą, ale stworzeniem. Wynika to jednak z jego rozumienia natury jako czegoś oczywistego, czegoś, co powstaje samo z siebie i nie potrzebuje do wyjaśnienia swojego istnienia żadnej zewnętrznej instancji. Ponieważ taka naturalistyczna interpretacja powstania świata jest nie do pogodzenia z chrześcijaństwem, Guardini odrzuca pojęcie natury i zastępuje je słowem ,stworzenie" ${ }^{10}$. Z drugiej strony, w języku potocznym słowa te używane są często jako synonimy. W kontekście ekologii mówi się np. o ochronie przyrody, ochronie środowiska naturalnego

\footnotetext{
${ }^{9}$ Por. G. KRaUS, Gotteserkenntnis ohne Offenbarung und Glaube?, s. 43.

${ }^{10}$ Por. R. GuARDini, Welt und Person. Versuche zur christlichen Lehre vom Menschen, Verlag Werkbund, Würzburg 1940, s. 13.
} 
i ochronie stworzenia, i wszystkie te określenia oznaczają w zasadzie to samo. Wielu ludzi wierzących używa słowa „natura” w znaczeniu świata przyrody jako tej części otaczającej nas rzeczywistości, która nie została utworzona przez człowieka, lecz jest dziełem Bożym. Właśnie dlatego uważam, że nie trzeba rezygnować z pojęcia natury, by zrobić miejsce dla wiary w stworzenie. Wręcz przeciwnie: jak najbardziej możliwe jest sformułowanie stricte teologicznego pojęcia natury, które nie stoi w opozycji do idei stworzenia, ale się z nią utożsamia.

Tego samego zdania jest niemiecki teolog Raphael Schulte, który w jednym ze swoich artykułów przedstawia właśnie takie pojęcie natury jako świata stworzonego oraz wypływające $\mathrm{z}$ niego konsekwencje ${ }^{11}$. Przede wszystkim rozumie on naukę o stworzeniu jako wypowiedź wiary na temat teraźniejszości, na temat rzeczywistości, której tu i teraz doświadczamy ${ }^{12}$. Nie chodzi więc tutaj tylko o określenie samego stwórczego działania Boga, ale przekonanie o tym, że ten świat, w którym żyjemy, ma swój początek i uzasadnienie swojego istnienia właśnie $\mathrm{w}$ dziele stworzenia, które z kolei ma swoje źródło w wolności i miłości Boga. Z takiego ujęcia „natury” jako „stworzenia” wynika jednak coś jeszcze, a mianowicie przekonanie o tym, że ma ona charakter objawienia, które w rozumieniu chrześcijańskim dotyczy Boga $^{13}$. I właśnie ta nauka o objawieniu się Boga w stworzeniu, które jest nazywane również pierwotnym lub uniwersalnym objawieniem, stoi u podstaw proponowanej przeze mnie teologii natury.

\section{TEOLOGIA NATURY JAKO POSZUKIWANIE ŚLADÓW BOGA W STWORZONYM ŚWIECIE}

Celem tego przedsięwzięcia jest teologiczna refleksja nad naturą jako światem stworzonym przez Boga i jednocześnie miejscem uniwersalnego objawienia się Boga. Inaczej mówiąc chodzi o poszukiwanie śladów Boga w stworzonym świecie $\mathrm{i}$ ich teologiczną interpretację. Tak rozumiana teologia natury może być rozwijana w ramach teologii fundamentalnej, której głównym zadaniem jest uzasadnianie wiarygodności Objawienia chrześcijańskiego

\footnotetext{
11 Zob. R. SChUlte, Natur als (Auf-)Gabe. Natur in der Perspektive der Theologie, w: Natur als Gegenstand der Wissenschaften, red. L. Honnefelder, Verlag Karl Alber, Freiburg-München 1992, s. 191-227.

12 Por. tamże, s. 203.

${ }^{13}$ Por. tamże, s. 206-209.
} 
w obliczu ludzkiego rozumu ${ }^{14}$. Wypełniając tę funkcję teologia fundamentalna bada współczesny kontekst wiary oraz podejmuje dialog z innymi tradycjami religijnymi i światopoglądami odrzucającymi chrześcijańską wizję świata i człowieka. Duże znaczenie ma również dialog z naukami przyrodniczymi, których osiągnięcia - zdaniem wielu współczesnych uczonych i filozofów kwestionują racjonalność wiary w Boga. Również tutaj ważną rolę może odegrać szeroko pojęta teologia natury, ściśle związana z rozwijaną, np. przez ks. prof. Michała Hellera, teologią nauki ${ }^{15}$.

Oczywiście, nie chodzi tutaj o formułowanie dowodów na istnienie Boga. To kluczowe dla tradycyjnej teologii naturalnej pojęcie jest we współczesnej refleksji teologicznej zastępowane innymi określeniami, takimi jak wskazówki na istnienie Boga czy też racjonalne argumenty za istnieniem Boga. Szczególnie ważne jest sformułowanie „ślady Boga” w stworzonym świecie, które bardziej akcentuje zakorzenienie tych wskazówek czy też argumentów w fakcie uniwersalnego objawienia się Boga w stworzeniu.

W ramach tak rozumianej teologii natury jest miejsce dla filozoficznych argumentów za istnieniem Boga, wśród których można wyróżnić argumenty kosmologiczne, teleologiczne oraz antropologiczne. Zwłaszcza w ramach proponowanej, np. przez Dominikusa Kraschla, argumentacji kolektywnej, tzn. uwzględniającej różne wzajemnie uzupełniające się argumenty ${ }^{16}$, mogą one odegrać ważną rolę $\mathrm{w}$ sporze między teizmem i ateizmem. Nie chodzi tu tylko o argumenty tradycyjne, takie jak np. pięć dróg św. Tomasza z Akwinu, ale też o współczesne próby racjonalnego uzasadnienia wiary w Boga. Jako przykład można podać sformułowane przez niemieckiego teologa Hansa Kesslera argumenty przemawiające za racjonalnością przekonania o istnieniu Boga jako praprzyczyny (niem. Urgrund) świata, w którym żyjemy. Kessler podkreśla, że nie chodzi w tym ujęciu o pierwszą przyczynę w łańcuchu przyczyn naturalnych, bo to sugerowałoby, że Bóg jest częścią świata, ale o absolutną podstawę uzasadniającą istnienie całego łańcucha ${ }^{17}$. W swojej

\footnotetext{
${ }^{14}$ Por. H. Seweryniak, Teologia fundamentalna, t. 1, Biblioteka „Więzi” 258, Towarzystwo „Więź”, Warszawa 2010, s. 16.

${ }^{15}$ Zob. M. Heller, Program teologii nauki, w: Nowa fizyka i nowa teologia, Wydawnictwo Biblos, Tarnów 2002; W.M. MACEK, Teologia nauki wedtug księdza Michała Hellera, Wydawnictwo UKSW, Warszawa 2014; Teologia nauki, red. J. Mączka, P. Urbańczyk, Copernicus Center Press, Kraków 2015; T. PABJAN, Anatomia konfliktu. Między nowym ateizmem a teologia nauki, Copernicus Center Press, Kraków 2016.

${ }^{16}$ Por. D. KRASCHL, Indirekte Gotteserfahrung. Ihre Natur und Bedeutung für die theologische Erkenntnislehre, QD 282, Verlag Herder, Freiburg im Breisgau, 2017, s. 201-205.

${ }^{17}$ Por. H. KESSLER, Gott - warum er uns nicht loslässt, topos taschenbücher 1091, Verlag
} 
argumentacji wychodzi on od doświadczenia kontyngencji, czyli niekonieczności istnienia świata i człowieka ${ }^{18}$. Następnie zwraca on uwagę na fenomen samoświadomości i nieograniczonej otwartości człowieka na świat. Kessler zastanawia się, jak natura miałaby sama z siebie stworzyć byt, który stawia pytania wykraczające poza rzeczywistość naturalną, np. pytania o genezę świata i sens istnienia, i dochodzi do wniosku, że jedynym racjonalnym uzasadnieniem tego faktu jest realne istnienie rzeczywistości ponadnaturalnej, która jest źródłem istnienia świata natury i człowieka oraz nadaje mu sens ${ }^{19}$. Ponadto Kessler zwraca uwagę na to, że historia ewolucji składa się z wielu ekstremalnie nieprawdopodobnych zdarzeń, bez których niemożliwe byłoby powstanie życia na Ziemi i pojawienie się człowieka. Szczególne znaczenie ma tu fakt, że fundamentalne stałe fizyczne w pierwszych sekundach po Wielkim Wybuchu miały dokładnie takie wartości, aby rozwinął się taki Wszechświat, w którym w pewnym momencie mogło powstać życie, w tym życie ludzkie. Nawet minimalna ich zmiana spowodowałaby, że byłoby to niemożliwe ${ }^{20}$. Oczywiście, nie jest to niepodważalny dowód na to, że świat został stworzony przez Boga, ale argument przemawiający za tym, że wiara w Boga jako praprzyczynę zawiera dobre wyjaśnienie faktu istnienia świata oraz jego początku i istnieją racjonalne przesłanki, aby ją przyjaćc. Niemniej jednak pozostaje ona wiarą, tzn. wolną decyzją człowieka podejmowaną bez ostatecznej i niepodważalnej pewności.

Ja jednak chciałbym się skupić na innym aspekcie, a mianowicie na relacji człowieka wierzącego do natury rozumianej jako miejsce objawienia się Boga oraz konsekwencji, jakie wynikają z takiego ujęcia dla nauki Kościoła i przepowiadania na tematy ekologiczne. Jak zauważa ewangelicki teolog Sigurd Daecke, problematyka ta ściśle wiąże się z teologią stworzenia oraz z naturalnym poznaniem Boga, rozumianym jako poznanie Boga z natury i poprzez naturę. Nie chodzi w nim bowiem tylko o coś teoretycznego i abstrakcyjnego, ale o poznanie Boga, który jest Bogiem aktywnym, działającym. Do teologii natury należy - według niego - również aspekt etyczny, polegający na tym, że jest ona wezwaniem do tego, abyśmy działali tak jak Stwórca, tzn. współdziałali $\mathrm{z}$ nim poprzez zaangażowanie $\mathrm{w}$ ochronę stworzenia ${ }^{21}$.

\footnotetext{
topos plus, Kevelaer 2016, s. 17.

${ }^{18}$ Por. tamże, s. 19-20.

${ }^{19}$ Por. tamże, s. 21-22

${ }^{20}$ Por. tamże, s. 22-23. Kessler podaje konkretne przykłady takich zdarzeń oraz warunków początkowych wszechświata, dzięki którym możliwe było powstanie życia i człowieka.

${ }^{21}$ Por. Evolution als Offenbarung - Kann man Gott aus der Natur erkennen? Zusammen-
} 


\section{OCHRONA PRZYRODY JAKO OBOWIAZZEK RELIGIJNY WYNIKAJĄCY Z WIARY W BOGA JAKO STWORZYCIELA ŚWIATA}

$\mathrm{Na}$ początku artykułu zacytowałem fragment z Księgi Mądrości mówiący o tym, że „z wielkości i piękna stworzeń poznaje się przez podobieństwo ich Stwórcę" (Mdr 13,5). Punktem wyjścia teologii natury, jako poszukiwania śladów Boga w stworzonym świecie, jest zatem obserwacja i kontemplacja przyrody oraz doświadczenie zachwytu nad jej wielkością i pięknem. Spontanicznie przychodzi mi w tym momencie na myśl wiosna, czas, kiedy przyroda budzi się do życia po zimowej przerwie. Bardzo lubię w tym czasie chodzić na spacery, podczas których doświadczam ciagle na nowo zachwytu nad tym, jak piękny jest świat przyrody. Podobne doświadczenia są udziałem wielu ludzi wędrujących po górach i odbywających podróże do różnych zakątków świata, aby zobaczyć przepiękne i budzące zachwyt krajobrazy. Również obserwowanie wschodów i zachodów słońca czy też oglądanie różnych gatunków roślin i zwierząt w ogrodach botanicznych czy zoologicznych może wzbudzać w nas podobne uczucia. Jako ludzie wierzący możemy interpretować takie doświadczenia $\mathrm{w}$ świetle wiary w stworzenie. Wywołują one w nas wdzięczność wobec Stwórcy, którego uwielbiamy za to, że stworzył tak piękny i wspaniały świat. Przykładem takiego uwielbienia Boga, wywołanego zachwytem nad pięknem stworzenia, jest Pieśń słoneczna św. Franciszka z Asyżu, której fragment cytuje Papież Franciszek na samym początku swojej ekologicznej encykliki. Zgodnie $\mathrm{z}$ tradycją te pierwsze słowa stanowią też tytuł dokumentu: Laudato si', mi' Signore - „Pochwalony bądź, Panie mój, przez siostrę naszą, matkę ziemię, która nas żywi i chowa, wydaje różne owoce z barwnymi kwiatami i trawami"22. Na innym miejscu Ojciec święty porównuje postawę Franciszka wobec świata przyrody do zakochania oraz relacji pomiędzy rodzeństwem: „Podobnie jak człowiek zakochany, Franciszek za każdym razem, kiedy spoglądał na słońce, księżyc czy najmniejsze zwierzęta, reagował śpiewem, włączając w swoje uwielbienie wszystkie stworze-

fassung eines Gesprächs, w: Kann man Gott aus der Natur erkennen?, red. C. Bresch, S.M. Daecke, H. Riedlinger, s. 155-174, tutaj: s. 173. Tekst ten jest zapisem dyskusji w programie pt. „Disputationes” na antenie telewizji OFR (emisja 26 kwietnia 1989), w której udział wzięli: genetyk Carsten Bresch, teolog ewangelicki Sigurd Daecke, biochemik Günter Kreil, filozof i teolog katolicki Béla Weissmahr SJ oraz pisarz i moderator Günther Schiwy.

22 FRANCISZEK Z ASYŻU, Pieśń słoneczna albo pochwała stworzeń, w: Źródta franciszkańskie, red. R. Prejs, Z. Kijas, Wydawnictwo Bratni Zew, Kraków 2005, s. 348. Cyt. za: FrANCISZEK, Encyklika Laudato si', nr 1. 
nia. [...] Jego reakcja była czymś więcej niż docenieniem intelektualnym lub kalkulacją ekonomiczną, bo dla niego wszelkie stworzenie było jak siostra, związana z nim więzami miłości. Dlatego czuł się powołanym, by zatroszczyć się o wszystko, co istnieje" 23 .

Właśnie to doświadczenie zachwytu i postawa wdzięczności wobec Boga i uwielbiania Go za to, że stworzył tak wielki, piękny i wspaniały świat, którego my również jesteśmy częścią, jest najgłębszym uzasadnieniem dla zaangażowania ludzi wierzących $\mathrm{w}$ ochronę środowiska naturalnego, która papież w podtytule encykliki nazywa „troską o wspólny dom”. W świetle przedstawionej wyżej teologii natury można ją traktować jako obowiązek religijny wynikający wprost $\mathrm{z}$ wiary w Boga jako Stworzyciela świata. Pisze o tym np. duński etyk i filozof religii Viggo Mortensen. Wskazuje on na to, że fakt stworzenia świata przez Boga oznacza, że Bóg go chce, że w oczach Bożych jest on dobry i wartościowy. $Z$ tego wynika określona postawa człowieka wobec przyrody, która została mu przez Boga powierzona i za która ponosi on przed Bogiem odpowiedzialność. Przykładem jest szacunek dla różnych form życia, który ma swoje źródło w przekonaniu, że życie ma wartość samą w sobie, wartość wynikającą z faktu, że powstało ono z woli Bożej i jest częścią Bożego planu ${ }^{24}$.

Oczywiście, encyklika Laudato si' nie jest pierwszą wypowiedzią Magisterium Kościoła na tematy ekologiczne. Były one już wielokrotnie poruszane przez poprzedników Franciszka: Pawła VI, Jana Pawła II i Benedykta XVI ${ }^{25}$. Niemniej jednak jest to pierwszy dokument poświęcony w całości tej niezwykle ważnej i aktualnej tematyce, co podkreśla jej znaczenie dla Kościoła naszych czasów. W tym kontekście powstaje pytanie, jak ma się to do kościelnego przepowiadania. O ile zarówno papież Franciszek jak i wielu biskupów, np. w Niemczech, gdzie obecnie mieszkam i pracuję, bardzo chętnie podejmuje w kazaniach tematy związane $\mathrm{z}$ ochroną stworzenia, to odnoszę wrażenie, że ciaggle niewiele mówi się na ten temat w kaznodziejstwie parafialnym, zarówno tym niedzielnym jak i okolicznościowym, np. w ramach rekolekcji, dni skupienia, pielgrzymek itd. Na zakończenie artykułu chciałbym podać kilka wskazówek, które mogą być w tym pomocne, a które mają swoje źródło w przedstawionej wcześniej teologii natury.

\footnotetext{
${ }^{23}$ FrANCISZEK, Encyklika Laudato si', nr 11.

${ }^{24}$ Por. V. Mortensen, Theologie der Natur als natürliche Theologie, s. 128-129.

${ }^{25}$ Zob. fragment encykliki Laudato si' nawiązujący do wypowiedzi wspomnianych papieży (nr 4-6).
} 


\section{PRZEPOWIADANIE NA TEMATY EKOLOGICZNE W ŚWIETLE TEOLOGII NATURY}

Pierwsza myśl dotyczy kalendarza liturgicznego. Niestety nie ma w nim żadnego święta, które dotyczyłoby bezpośrednio dzieła stworzenia świata, analogicznie do świąt związanych z wydarzeniami z historii zbawienia. Mimo to nie brakuje okazji do poruszania w kazaniach tematów związanych ze stworzeniem i jego ochroną. Jedną z nich są na przykład dożynki. W Niemczech jest to święto obchodzone we wszystkich parafiach, także w miastach, najczęściej w pierwszą niedzielę października. Ma ono charakter dziękczynienia, nie tylko za zebrane plony ziemi, ale za wszelkie Boże dary, w tym także za wspaniały i piękny świat, w którym żyjemy, a który jest Jego dziełem. Myślę, że warto, aby także w Polsce dożynki stały się stałym elementem liturgicznego kalendarza we wszystkich parafiach. Jest to bowiem świetna okazja do głoszenia kazań mówiących o pięknie stworzenia i zachęcających do postawy wdzięczności i uwielbienia wobec Stwórcy. Również w inne dni, gdy czytany jest np. opis stworzenia świata z Księgi Rodzaju albo też wspomniane na początku artykułu teksty z Księgi Mądrości czy Listu do Rzymian, jak również gdy śpiewane są psalmy wysławiające Boga za piękno stworzenia, można w kazaniach zachęcać wiernych do zaangażowania w inicjatywy służące ochronie środowiska naturalnego, wskazując na to, że jest to naszym chrześcijańskim obowiązkiem zakorzenionym w wierze w Boga jako Stworzyciela świata. Jeszcze inną świetną okazją do poruszenia tematów ekologicznych są piesze pielgrzymki, w czasie których wierni mają bardzo bezpośredni kontakt z przyrodą.

Poza tekstami biblijnymi można w kazaniach dotyczących ochrony stworzenia sięgać do innych źródeł, np. do wspomnianej już wielokrotnie encykliki Laudato si', która zawiera wiele pięknych i napisanych zrozumiałym językiem fragmentów, czy też do katechez św. Jana Pawła II o Bogu Ojcu Stworzycielu, wygłoszonych podczas audiencji środowych w 1986 roku $^{26}$. Podobnie jak papież Franciszek można też nawiązać do postaci św. Franciszka z Asyżu oraz jego tekstów, np. „Pieśni słonecznej”.

Również teologia natury może być impulsem do wygłoszenia kazania, w którym świat przyrody zostanie pokazany jako miejsce objawienia się Boga, jako księga stworzenia, w której Pan Bóg do nas mówi podobnie jak

\footnotetext{
${ }^{26}$ JAN PAWEŁ II, Wierze w Boga Ojca Stworzyciela. Katechezy roku 1986, Libreria Editrice Vaticana, Watykan 1987.
} 
w Piśmie Świętym, ukazując nam swoją dobroć i swoje piękno. Takie ujęcie pozwoli wzbudzić w słuchaczach religijną motywację do troski o środowisko naturalne. Tak jak Biblia powinna być otaczana najwyższym szacunkiem ze względu na zawarte w niej słowo Boże, tak samo chrześcijanie powinni szanować przyrodę jako księgę stworzenia, w której możemy poznać i kontemplować Boga jako Stworzyciela świata. Taka refleksja może być punktem wyjścia do zastanowienia się nad naszym życiem, nad naszymi postawami wobec świata przyrody, do rachunku sumienia dotyczącego grzechów i zaniedbań z tym związanych. Naśladując papieża Franciszka, powinniśmy wzywać wiernych do nawrócenia ekologicznego ${ }^{27}$. Ojciec święty zachęca w tym kontekście do wdzięczności i bezinteresowności, do uznania, ,że świat jest darem otrzymanym z miłości Ojca”, a także do „rozwijania swojej kreatywności i entuzjazmu, by rozwiązać problemy świata"28. Motywacją do tego powinna być - według Papieża - między innymi „świadomość, że każde stworzenie odzwierciedla coś z Boga i zawiera orędzie, które ma nam przekazać”, a także uznanie, ,że ponieważ Pan Bóg stworzył świat, wpisując weń pewien ład i dynamizm, to człowiek nie ma prawa ich ignorować" ${ }^{29}$. Wyraźnie nawiązuje on tu do tego, na co zwraca uwagę teologia natury. Myślę, że wszyscy głosiciele Bożego słowa powinni potraktować te słowa Franciszka jako zachętę i wezwanie do tego, aby przekazywać to nauczanie naszym wiernym w kazaniach i katechezach ${ }^{30}$.

Na zakończenie chciałbym zacytować fragment „Chrześcijańskiej modlitwy wraz ze stworzeniem", która nie tylko wieńczy encyklikę Laudato si', ale jest też dobrym podsumowaniem tego artykułu. Słowa te jeszcze raz podkreślaja znaczenie tematyki ekologicznej dla Kościoła naszych czasów oraz jej zakorzenienie $\mathrm{w}$ opartej na idei uniwersalnego objawienia Boga $\mathrm{w}$ stworzonym świecie teologii natury.

${ }^{27}$ Por. FranciszeK, Encyklika Laudato si', nr 216-221. Por. A. WaŁowsKA, Elementy duchowości ekologicznej w encyklice papieża Franciszka Laudato si’, „Studia TeologicznoHistoryczne Śląska Opolskiego" 38(2018), nr 1, s. 147-157.

${ }^{28}$ FrANCISZEK, Encyklika Laudato si', nr 220.

${ }^{29}$ Tamże, nr 221.

${ }^{30}$ Zob. J. KostorZ, Katechetyczne znaczenie encykliki Laudato si', „Studia Oecumenica” 15(2015), s. 69-79. 
Panie Boże w Trójcy Jedyny, piękna Wspólnoto nieskończonej miłości, naucz nas kontemplowania Ciebie

w pięknie wszechświata,

gdzie wszystko mówi nam o Tobie.

Rozbudź nasze uwielbienie i wdzięczność

za każdą istotę, którą stworzyłeś.

Obdarz nas łaską poczucia się wewnętrznie zjednoczonymi

z wszystkim, co istnieje.

Boże miłości, ukaż nam nasze miejsce w tym świecie

jako narzędzi Twojej miłości

dla wszystkich istot tej ziemi,

bo żadna z nich nie jest przez Ciebie zapomniana.

Oświeć posiadających władzę i pieniądze,

aby nie popadli w grzech obojętności,

aby miłowali dobro wspólne, wspierali słabych

i opiekowali się światem, w którym żyjemy.

Ubodzy i ziemia wołają:

Panie, obejmij nas swą mocą i światłem,

abyśmy chronili wszelkie życie,

przygotowali lepszą przyszłość,

aby nadeszło Twoje Królestwo

sprawiedliwości, pokoju, miłości i piękna.

Pochwalony bądź, Panie!

Amen ${ }^{31}$.

\section{BIBLIOGRAFIA}

BARTH K., Katholische Dogmatik, II/1, Theologischer Verlag, Zürich 1940.

BARTH K., Nein! Antwort auf Emil Brunner, Verlag C. Kaiser, München 1934.

BERGER D., Natur und Gnade in systematischer Theologie und Religionspädagogik von der Mitte des 19. Jahrhunderts bis zur Gegenwart, Verlag Roderer, Regensburg 1998.

Evolution als Offenbarung - Kann man Gott aus der Natur erkennen? Zusammenfassung eines Gesprächs, w: Kann man Gott aus der Natur erkennen?, red. C. Bresch, S.M. Daecke, H. Riedlinger, Verlag Herder, Freiburg im Breisgau 1990, s. 155-174.

FrANCISZEK, Encyklika Laudato si'. W trosce o wspólny dom, Wydawnictwo M, Kraków 2015.

FRANCISZEK Z ASYŻU, Pieśń słoneczna albo pochwała stworzeń, w: Źródła franciszkańskie, red. R. Prejs, Z. Kijas, Wydawnictwo Bratni Zew, Kraków 2005.

GuARDini R., Welt und Person. Versuche zur christlichen Lehre vom Menschen, Verlag Werkbund, Würzburg 1940.

\footnotetext{
${ }^{31}$ FrANCISZEK, Encyklika Laudato si', nr 153-154.
} 
Heller M., Program teologii nauki, w: Nowa fizyka i nowa teologia, Wydawnictwo Biblos, Tarnów 2002.

JAN PAWEe II, Wierzę w Boga Ojca Stworzyciela. Katechezy roku 1986, Libreria Editrice Vaticana, Watykan 1987.

KESSLER H., Gott - warum er uns nicht loslässt, topos taschenbücher 1091, Verlag topos plus, Kevelaer 2016.

Koch T., Natur und Gnade. Zur neueren Diskussion, „Kerygma und Dogma” 16(1970), s. 171187.

Kolmer P., Warum Streit um die Evolutionstheorie? Anmerkungen zur Vereinbarkeit von Glauben und Wissen, w: Gott und Natur. Philosophische Positionen zum aktuellen Streit um die Evolutionstheorie, red. P. Kolmer, K. Köchy, Verlag Karl Alber, Freiburg-München 2011, s. 13-50.

Kostorz J., Katechetyczne znaczenie encykliki Laudato si', „Studia Oecumenica” 15(2015), s. $69-79$.

KRASCHL D., Indirekte Gotteserfahrung. Ihre Natur und Bedeutung für die theologische Erkenntnislehre, QD 282, Verlag Herder, Freiburg im Breisgau 2017.

KRAUS G., Gotteserkenntnis ohne Offenbarung und Glaube? Natürliche Theologie als ökumenisches Problem, Bonifatius-Druckerei, Paderborn 1987.

KÜHN U., Natur und Gnade. Untersuchungen zur deutschen katholischen Theologie der Gegenwart, Evangelische Verlagsanstalt, Berlin 1961.

MACEK W.M., Teologia nauki według księdza Michała Hellera, Wydawnictwo UKSW, Warszawa 2014.

MARCZAK P., Problemy ekologiczne jako problemy społeczne, Seria Socjologia nr 27, Uniwersytet Adama Mickiewicza, Poznań 2000.

Mortensen V. Theologie der Natur als natürliche Theologie, w: Kann man Gott aus der Natur erkennen? Evolution als Offenbarung (QD 125), red. C. Bresch, S.M. Daecke, H. Riedlinger, Verlag Herder, Freiburg im Breisgau 1990, s. 117-134.

PABJAn T., Anatomia konfliktu. Między nowym ateizmem a teologią nauki, Copernicus Center Press, Kraków 2016.

RAHNER K., Über das Verhältnis von Natur und Gnade, w: Schriften zur Theologie I, 4. Auflage, Verlag Benziger, Einsiedeln 1960.

SCHUlte R., Natur als (Auf-)Gabe. Natur in der Perspektive der Theologie, w: Natur als Gegenstand der Wissenschaften, red. L. Honnefelder, Verlag Karl Alber, Freiburg-München 1992, s. 191-227.

SEWERYNIAK H., Teologia fundamentalna, t. 1, Biblioteka „Więzi” 258, Towarzystwo „Więź”, Warszawa 2010.

Simonis W., Natur und Gnade, „Catholica - Münster” 19(1965), s. 310-324.

Teologia nauki, red. J. Mączka, P. Urbańczyk, Copernicus Center Press, Kraków 2015.

WaŁOWSKA A., Elementy duchowości ekologicznej w encyklice papieża Franciszka Laudato si', ,Studia Teologiczno-Historyczne Śląska Opolskiego” 38(2018), nr 1, s. 147-157. 


\title{
ŚLADY BOGA W STWORZONYM ŚWIECIE. TEOLOGIA NATURY A NAUCZANIE KOŚCIOŁA I PRZEPOWIADANIE NA TEMATY EKOLOGICZNE
}

\author{
St res z c z e n i e
}

Encyklika papieża Franciszka Laudato si' pokazuje, jak duże znaczenie dla Kościoła naszych czasów mają tematy ekologiczne. Nie powinno ich zabraknąć również w przepowiadaniu słowa Bożego. Niniejszy artykuł stanowi próbę odpowiedzi na to wyzwanie w oparciu o teologię natury, polegającą na poszukiwaniu śladów Boga w świecie. Jej punktem wyjścia jest teologiczne pojęcie natury jako stworzenia oraz idea uniwersalnego objawienia się Boga w stworzonym świecie. Po omówieniu głównych założeń teologii natury przedstawione zostały etyczne konsekwencje takiego ujęcia (ochrona przyrody jako obowiązek religijny wynikający z wiary w Boga jako Stworzyciela świata) oraz wskazówki dotyczące możliwości wykorzystania impulsów wypływających $\mathrm{z}$ teologii natury w kościelnym przepowiadaniu.

Słowa kluczowe: natura; stworzenie; uniwersalne objawienie; ekologia; ochrona przyrody; przepowiadanie słowa Bożego. 